\title{
A re-evaluation of the taxonomy of Paracoccus denitrificans and a proposal for the combination Paracoccus pantotrophus comb. nov.
}

\author{
Frederick A. Rainey, ${ }^{1}$ Donovan P. Kelly, ${ }^{2}$ Erko Stackebrandt, ${ }^{3}$ \\ Jutta Burghardt, ${ }^{3}$ Akira Hiraishi, ${ }^{4}$ Yoko Katayama ${ }^{5}$ and Ann P. Wood ${ }^{6}$
}

Author for correspondence: Donovan P. Kelly. Tel: +44 1203 572907. Fax: +44 1203523701.

e-mail:mmza@dna.bio.warwick.ac.uk

\footnotetext{
1 Department of Biological Sciences, Louisiana State University, Baton Rouge, LA 70803, USA

2 Department of Biological Sciences, University of Warwick, Coventry CV4 7AL, UK

${ }^{3}$ DSMZ - Deutsche Sammlung von

Mikroorganismen und Zellkulturen $\mathrm{GmbH}$, Mascheroder Weg 1b, D38124 Braunschweig, Germany

4 Department of Ecological Engineering, Toyohashi University of Technology, Tenpaku-cho, Toyohashi 441, Japan

5 Department of Environmental and Natural Resources Science, Tokyo University of Agriculture and Technology, Fuchu 183, Japan

6 Microbiology Research Group, Division of Life Sciences, King's College London, Campden Hill Road, London W8 7AH, UK
}

\begin{abstract}
Comparison of both 165 rRNA coding sequences and DNA-DNA hybridization of ten strains of $\alpha$-subclass of Proteobacteria currently classified as strains of Paracoccus denitrificans has shown that they fall into two groups which are distinct from each other at the species level. Comparison with published data on the cytochrome $c$ profiles and other 16S rRNA coding sequences in the literature has confirmed these observations and enabled several other strains also to be assigned to these two groups. Group A comprises strains ATCC $17741^{\top}$ (the type strain of $P$. denitrificans), LMD 22.21', DSM 413', ATCC 19367, ATCC 13543, DSM 1404, DSM 1405, Pd 1222 (a genetic modification of DSM $4^{1} 3^{\top}$ ) and NCIMB 8944. Group B comprises ATCC $35512^{\top}$ (the original type strain of Thiosphaera pantotropha), LMD 82.5', LMD 92.63, DSM 65, LMG 4218, IAM 12479, JCM 6892, DSM 11072, DSM 11073 and DSM 11104. In light of these findings, it is proposed that: (1) strains of group $A$ are retained as $P$. denitrificans, with ATCC $17741^{\top}$ as the type strain of the type species; and (2) all strains of group B are assigned to the new species combination Paracoccus pantotrophus comb. nov., with strain ATCC $35512^{\top}$ as the type strain. Comparative 165 rRNA sequence analysis and DNA-DNA hybridization of strains of Paracoccus versutus confirm that this species is distinct from both $P$. denitrificans and $P$. pantotrophus, but that its nearest phylogenetic neighbour is $P$. pantotrophus.
\end{abstract}

Keywords: Paracoccus denitrificans, Paracoccus pantotrophus, Thiosphaera, 16S rRNA gene sequencing, DNA-DNA hybridization

\section{INTRODUCTION}

The genus Paracoccus and its type species Paracoccus denitrificans (Beijerinck \& Minkman, 1910; formerly 'Micrococcus denitrificans' Beijerinck 1910) were defined by Davis et al. (1969) in their assignment of 'hydrogen bacteria' to a variety of new and existing genera. The type strain was established as ATCC (American Type Culture Collection, Manassas, VA, USA) $17741^{\mathrm{T}}$ (formerly 'Micrococcus denitrificans'

The EMBL accession numbers for the 165 rRNA gene sequences reported in this paper are given in Table 1.
Beijerinck 1910), with other extant examples of the original isolate being LMD (Delft Collection of Microorganisms, Delft, The Netherlands) $22.21^{\mathrm{T}}$, ATCC 19367 and ATCC 13543 (Davis et al., 1969). Numerous similar isolates were subsequently assigned to $P$. denitrificans, which became recognized as a heterogeneous species comprising several biotypes (Jordan et al., 1997; Van Verseveld \& Stouthamer, 1992). A related single-species genus, Thiosphaera pantotropha (Robertson \& Kuenen, 1983), was also assigned to $P$. denitrificans on the basis of analysis of the base sequence of the 16S rRNA gene (Ludwig et al., 1993).

Recently, the history of the strains in culture 
Table 1. Strains of Paracoccus and Thiosphaera compared in this study: sources and accession numbers for their $16 \mathrm{~S}$ rRNA gene sequences

ATCC, American Type Culture Collection, Manassas, VA, USA; DSMZ, Deutsche Sammlung von Mikroorganismen und Zellkulturen, Braunschweig, Germany; IAM, Institute of Applied Microbiology, University of Tokyo, Tokyo, Japan; JCM, Japan Collection of Microorganisms, Saitama, Japan; LMD, Delft Collection of Microorganisms, Delft, The Netherlands; LMG, Ghent Collection of Microorganisms, Ghent, Belgium.

\begin{tabular}{|c|c|c|c|c|}
\hline Organism & Strain no. & Source & Accession no. & Reference \\
\hline Paracoccus denitrificans & ATCC $17741^{\mathrm{T}}$ & C. Goodhew & Y16927 & This study \\
\hline Paracoccus denitrificans & ATCC 19367 & ATCC & Y16930 & This study \\
\hline Paracoccus denitrificans & LMD $22.21^{\mathrm{T}}$ & C. Goodhew & Y16928 & This study \\
\hline Paracoccus denitrificans & DSM $413^{\mathrm{T}}$ & DSMZ & Y16929 & This study \\
\hline Paracoccus denitrificans & LMG 4218 & LMG & X69159 & Ludwig et al. (1993) \\
\hline Paracoccus denitrificans & LMG 4218 & C. Goodhew & Y16936 & This study \\
\hline Paracoccus denitrificans & DSM 65 & DSMZ & Y16935 & This study \\
\hline Paracoccus denitrificans & IAM 12479 & IAM & Y17512 & This study \\
\hline Paracoccus denitrificans & JCM 6892 & JCM & Y17511 & This study \\
\hline Paracoccus denitrificans $\mathrm{KL} 1$ & DSM 11073 & DSMZ & U58017 & Jordan et al. (1997) \\
\hline Paracoccus denitrificans KS1 & DSM 11072 & DSMZ & U58015 & Jordan et al. (1997) \\
\hline Paracoccus denitrificans $\mathrm{KS} 2$ & DSM 11104 & DSMZ & U58016 & Jordan et al. (1997) \\
\hline Thiosphaera pantotropha & $\operatorname{ATCC} 35512^{\mathrm{T}}$ & ATCC & Y16933 & This study \\
\hline Thiosphaera pantotropha & LMD 92.63 & S. Baker & Y16934 & This study \\
\hline Thiosphaera pantotropha $\mathrm{GB} 17^{\mathrm{T}}$ & LMD $82.5^{\mathrm{T}}$ & L. A. Robertson & $\mathrm{X} 69159$ & Ludwig et al. (1993) \\
\hline Paracoccus versutus & IAM 12814 & IAM & D32243 & Katayama et al. (1995) \\
\hline Paracoccus versutus & ATCC $25364^{\mathrm{T}}$ & ATCC & Y16932 & This study \\
\hline Paracoccus versutus & DSM 582 & DSMZ & Y16931 & This study \\
\hline Paracoccus thiocyanatus & IAM $12816^{\mathrm{T}}$ & IAM & D32242 & Katayama et al. (1995) \\
\hline Paracoccus kocurii & $\mathrm{JCM} 7684^{\mathrm{T}}$ & JCM & D32241 & Katayama et al. (1995) \\
\hline Paracoccus aminophilus & $\mathrm{JCM} 7686^{\mathrm{T}}$ & JCM & D42239 & Katayama et al. (1995) \\
\hline Paracoccus alcaliphilus & $\mathrm{JCM} 7364^{\mathrm{T}}$ & JCM & D32238 & Katayama et al. (1995) \\
\hline Paracoccus aminovorans & $\mathrm{JCM} 7685^{\mathrm{T}}$ & JCM & D32240 & Katayama et al. (1995) \\
\hline Paracoccus solventivorans & DSM $6637^{\mathrm{T}}$ & DSMZ & Y07705 & Siller et al. (1996) \\
\hline
\end{tabular}

collections in relation to the sources of the original isolates was examined by comparative analysis of their $c$-type cytochrome and protein profiles, and the case for the reclassification of these strains into more than one species was considered (Goodhew et al., 1996). Using 16S rRNA sequence analysis, three new isolates of carbon-disulfide-using facultative chemolithotrophs were assigned to $P$. denitrificans (Jordan et al., 1995, 1997). This classification, like those used by Ludwig et al. (1993) in classifying $T$. pantotropha, as well as for our and Urakami's descriptions of several new Paracoccus species (Katayama et al., 1995; Ohara et al., 1990; Urakami et al., 1989, 1990), relied on the 16S rRNA sequence reported by Ludwig et al. (1993) for $P$. denitrificans LMG (Ghent Collection of Microorganisms, Ghent, Belgium) 4218, supposedly a derivative of the type strain. The study of Goodhew et al. (1996) cast doubt on the authenticity of strain LMG 4218 as being representative of the type strain and indicated that this strain and $T$. pantotropha were different at the species level from the $P$. denitrificans type strain, ATCC $17741^{\mathrm{T}}$. Consequently, a comparative analysis of the $16 \mathrm{~S}$ rRNA sequences was undertaken, complemented by examination of DNA-
DNA hybridization, to establish the relationship between the key culture collection strains of $P$. denitrificans, $T$. pantotropha and the other strains recently designated as $P$. denitrificans. The taxonomic position of Paracoccus versutus, which is closely related to $P$. denitrificans and $T$. pantotropha, has also been reinvestigated to establish whether it can remain as a valid species distinct from other Paracoccus species.

\section{METHODS}

Bacterial strains. The strains used directly in this study and those referred to in the Discussion are listed in Table 1. Paracoccus halodenitrificans [DSM (DSMZ, Deutsche Sammlung von Mikroorganismen und Zellkulturen, Braunschweig, Germany) 735, CCM (Czech Collection of Microorganisms, J. E. Juryne University, Brno, Czech Republic) 286; Van Verseveld \& Stouthamer, 1992] is excluded from consideration because it was subsequently shown to be a member of the genus Halomonas in the $\gamma$-subclass of the Proteobacteria (Dobson \& Franzmann, 1996; Miller et al., 1994; Ohara et al., 1990; Urakami et al., 1990). Two separate sources of the type strain of $P$. versutus were used: (1) the original isolate deposited by D. S. Hoare with the ATCC as ATCC $25364^{\mathrm{T}}$ [this was initially called Thiobacillus strain A2 
(Taylor \& Hoare, 1969), subsequently renamed Thiobacillus versutus (Harrison, 1983), then reassigned to Paracoccus (Katayama et al., 1995)]; and (2) the culture supplied by D. S. Hoare to D. P. Kelly in 1970 and deposited by D. P. Kelly with the DSMZ as DSM 582.

DNA isolation and determination of DNA-DNA hybridization. The DNA was isolated as described by Cashion et al. (1977). DNA hybridization was carried out according to De Ley et al. (1970) with modifications as described by Escara \& Hutton (1980) and Huß et al. (1983) using a Gilford System 2600 spectrophotometer equipped with a Gilford 2527-R thermoprogrammer and plotter. Renaturation rates were computed by the program TRANSFER.BAS (Jahnke, 1992).

Isolation of genomic DNA and determination of 16S rRNA gene sequences. Genomic DNA was extracted and subjected to PCR-mediated amplification of the $16 \mathrm{~S}$ rRNA coding sequences as described by Rainey et al. (1996). The purified PCR products were directly sequenced using described protocols (Rainey et al., 1996) and the sequence reaction mixtures were electrophoresed using an Applied Biosystems model 310 Genetic Analyzer. The 16S rRNA coding sequences of strains IAM (Institute of Applied Microbiology, University of Tokyo, Tokyo, Japan) 12479 and JCM (Japan Collection of Microorganisms, Saitama, Japan) 6892 were determined both by direct sequencing and by a combination of cloning and cycle sequencing (Hiraishi, 1992; Hiraishi et al., 1994, 1995). The 16S rRNA gene sequences were manually aligned with members of the alpha-2 subclass of the Proteobacteria using the ae 2 editor (Maidak et al., 1994). Evolutionary distances were calculated by the method of Jukes \& Cantor (1969). Phylogenetic dendrograms were reconstructed using tree algorithms contained in the PHYLIP package (Felsenstein, 1993).

\section{RESULTS AND DISCUSSION}

\section{Implications of studies on the c-type cytochrome profiles and the structure of cytochrome c-550 of strains of $\boldsymbol{P}$. denitrificans}

The work carried out by Goodhew et al. (1996) showed that the ten strains studied fell into two distinct groups, whose origins could each be traced to distinct original isolates of organisms, subsequently classified as Paracoccus denitrificans. These were the type strain isolated by Beijerinck in 1909 (Beijerinck \& Minkman, 1910) and a strain isolated by Koster (Goodhew et al., 1996). These were deposited in the Delft Culture Collection as LMD $22.21^{\mathrm{T}}$ and LMD 52.44 in 1922 and 1952, respectively. One group, representing the original Beijerinck type strain, was shown to contain culture collection strains ATCC $17741^{\mathrm{T}}$, ATCC 13543, ATCC 19367, DSM 413 ${ }^{\mathrm{T}}$, LMD $22.21^{\mathrm{T}}$, NCIMB (National Collection of Marine and Industrial Bacteria, Aberdeen, UK) 8944 and $P$. denitrificans Pd 1222 (a genetically modified strain of DSM $413^{\mathrm{T}}$; Goodhew et al., 1996). The other group, informally proposed to be a distinct species, comprised culture collection strains DSM 65, LMD 52.44 and LMG 4218. Representative examples from each group, and other isolates including two strains of Thiosphaera pantotropha, were subjected to comparative analysis by $16 \mathrm{~S}$ rRNA sequence analysis and DNA-DNA hybridization.

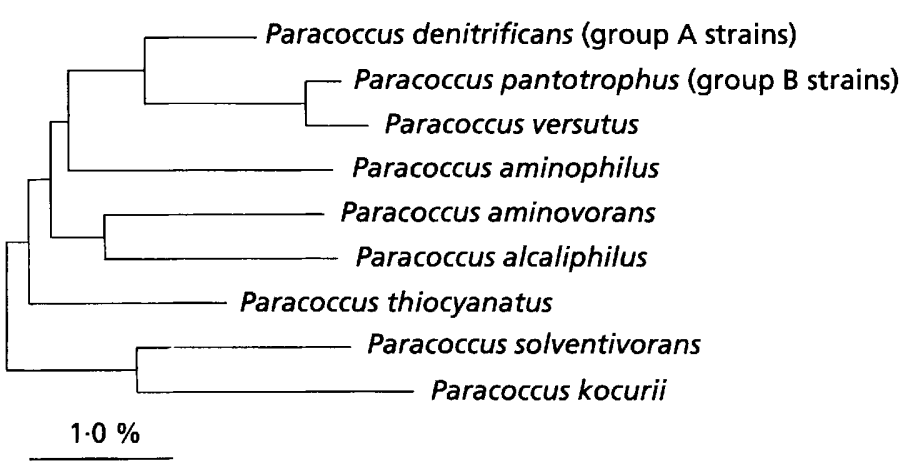

Fig. 1. Phylogenetic tree based on $16 S$ rRNA gene sequence data analysis of members of the genus Paracoccus. The scale bar represents 1 inferred nucleotide change per 100 nucleotides.

\section{Comparison of 165 rRNA sequences for strains of $P$. denitrificans and $T$. pantotropha}

Nearly complete 16S rRNA nucleotide coding sequences ( $>95 \%$ of the Escherichia coli sequence) were determined for ten strains held in culture collections as $P$. denitrificans or T. pantotropha, as well as two strains of $P$. versutus. The sequences determined for two $P$. denitrificans strains (IAM 12479 and JCM 6892) comprised $1421 \mathrm{nt}$ corresponding to positions 28-1524 of $E$. coli 16S rRNA (Brosius et al., 1978). The sequences for the other six $P$. denitrificans strains and two $T$. pantotropha strains comprised $1391 \mathrm{nt}$ between $E$. coli positions 38 and 1511, whereas the sequences of the two $P$. versutus strains comprised $1391 \mathrm{nt}$ between the same E. coli positions. These sequences, along with those available from the public databases (Table 1), were aligned and 1369 unambiguous positions between $E$. coli positions 38 and 1489 were used in the phylogenetic analyses and calculation of 16S rRNA gene sequence similarity values. The results of these analyses showed that the $P$. denitrificans and $T$. pantotropha strains fell into two distinct groups (Fig. 1). Group A comprised $P$. denitrificans strains ATCC $17741^{\mathrm{T}}$, ATCC 19367, DSM 413 ${ }^{\mathrm{T}}$ and LMD $22.21^{\mathrm{T}}$, whose 16S rRNA sequences were $100 \%$ identical to each other. Group B comprised $P$. denitrificans strains DSM 65, LMG 4218, IAM 12479 and JCM 6892, and T. pantotropha strains ATCC $35512^{\mathrm{T}}$ and LMD 92.63 . The 16S rRNA gene sequences of all of these strains were $100 \%$ identical to each other. Strain DSM 65 is currently listed in the DSMZ catalogue of strains as the type strain of $P$. denitrificans, and was reportedly originally received as 'strain 381 ' from R. Y. Stanier. As strain DSM 65 is not phylogenetically identical to strain ATCC $17741^{\mathrm{T}}$, it should not be regarded as the type strain. This conclusion was also drawn by Goodhew et al. (1996), who pointed out that the 'Stanier strain 381' cannot have given rise to both ATCC $17741^{\mathrm{T}}$ and DSM 65 , as stated in the respective culture collection catalogues. The group B sequence was also identical to that reported for $P$. denitrificans strain LMG 4218 (sequence X69159) and for $T$. 
pantotropha strain GB17 ${ }^{\mathrm{T}}$ (Ludwig et al., 1993), and showed $>99 \%$ similarity to the three carbon-disulfideusing strains recently classified as $P$. denitrificans DSM 11072, DSM 11073 and DSM 11104 (Jordan et al., 1997). The similarity between members of groups A and $\mathrm{B}$ was $98 \cdot 1 \%$ in all cases.

These results are absolutely consistent with the cytochrome-based deductions of Goodhew et al. (1996). On the basis of strain ATCC $17741^{\mathrm{T}}$ being the formally accepted type strain (Davis et al., 1969; Van Verseveld \& Stouthamer, 1992), 16S rRNA sequence analysis indicated that the following strains were all $P$. denitrificans: ATCC $17741^{\mathrm{T}}$, LMD $22.21^{\mathrm{T}}$, DSM $413^{\mathrm{T}}$ and ATCC 19367. The following strains are not $P$. denitrificans and all contain the 16S rRNA sequence originally found for the type strain of $T$. pantotropha: $P$. denitrificans strains DSM 65 and LMG 4218, and $T$. pantotropha strains ATCC $35512^{\mathrm{T}}$ and LMD 92.63. The $100 \%$ identity of the $16 \mathrm{~S}$ rRNA sequences of ATCC $35512^{\mathrm{T}}$ and LMD $82.5^{\mathrm{T}}$ (an original deposition of the type strain of $T$. pantotropha) also confirms the identity of these two strains. In addition, strains IAM 12479 and JCM 6892 from the Japanese culture collections, supposedly derived from the type strain ATCC $17741^{\mathrm{T}}$, were found to fall into the Thiosphaera group. The carbon-disulfide-using strains (Jordan et al., 1997) are also members of this group.

\section{DNA-DNA hybridization between strains of $P$. denitrificans}

Hybridization of DNA from $P$. denitrificans strains DSM 65, DSM 413 ${ }^{\mathrm{T}}$, DSM 11073 and DSM 11104 showed that three of these comprised one group (DSM 65,11073 and 11104), with DSM $413^{\mathrm{T}}$ showing significantly lower DNA-DNA hybridization with this group at the species level (Table 2).

These results are consistent with the conclusions of Goodhew et al. (1996) and our 16S rRNA sequence data concerning the relationship of DSM $413^{\mathrm{T}}$ and DSM 65, which are clearly not related at the species level. DSM $413^{\mathrm{T}}$ is representative of the type species, $P$. denitrificans, but DSM 65, DSM 11073 and DSM 11104 are representative of the $T$. pantotropha group.

\section{Comparison of 165 rRNA gene sequences and DNA-DNA hybridization between $P$. versutus and $P$. denitrificans}

The 16S rRNA sequences determined for $P$. versutus strains ATCC $25364^{\mathrm{T}}$ and DSM 582 were identical to each other and differed in one nucleotide position from the sequence previously reported for other culture collection strains of $P$. versutus (Katayama et al., 1995). Comparison of the $P$. versutus 16S rRNA sequence with the sequences for $P$. denitrificans DSM 65 and DSM $413^{\mathrm{T}}$ showed 99.3 and $97.4 \%$ similarity, respectively. Hybridization between DNA from the $P$. versutus strain DSM 582 and $P$. denitrificans strains DSM 65 and DSM $413^{\mathrm{T}}$ showed low hybridization
(Table 2). P. versutus is thus confirmed as a distinct species, with the DSM 65 group of strains (group B; including $T$. pantotropha) as its closest phylogenetic neighbour.

\section{Comparisons from the literature of 165 rRNA sequences and DNA-DNA hybridization between Paracoccus species}

All other published 16S rRNA gene sequence comparisons have used the sequence from strain $\mathrm{LMG}$ 4218 as representing the type strain of $P$. denitrificans (Katayama et al., 1995; Ludwig et al., 1993). Ludwig et al. (1993) previously showed that the sequence from strain LMG 4218 had $100 \%$ identity with that of strain GB17 $7^{\mathrm{T}}$ of Thiosphaera pantotropha (obtained as LMD 82.5 ; Chandra \& Friedrich, 1986). Their demonstration of $85 \%$ DNA-DNA hybridization between $T$. pantotropha LMD $82.5^{\mathrm{T}}$ and $P$. denitrificans DSM 65 seemed to support their conclusion that $T$. pantotropha was a strain of $P$. denitrificans, but this actually confirms our finding that DNA from DSM 65 (and IAM 12479; Katayama et al., 1995) is homologous at the species level with that of $T$. pantotropha, which is different from that of $P$. denitrificans. In another study, Ohara et al. (1990) found only $61 \%$ DNA-DNA hybridization between $P$. denitrificans strains IAM 12479 and IFO 13301. Since our results show that IAM 12479 is not representative of the type strain of $P$. denitrificans, but falls into the $T$. pantotropha group, strain IFO 13301 may be properly regarded as a derivative of the type strain of $P$. denitrificans. Strain IFO 13301 was reported to be identical to strains ATCC 19367 and DSM 413 (Urakami et al., 1989), which have been shown to have the same 16S rRNA sequence as the type strain ATCC $17741^{\mathrm{T}}$. It is also noteworthy that DNA-DNA hybridization showed $P$. denitrificans ATCC $17741^{\mathrm{T}}$ to exhibit 77 and $87 \%$ similarity to $P$. denitrificans strains DSM 1404 and DSM 1405, respectively (Urakami et al., 1989), showing that these strains and strain IFO 13301 were correctly classified as strains of $P$. denitrificans.

Katayama et al. (1995) showed that the 16S rRNA sequences (D32238-D32242; Table 1) of five species of Paracoccus were only $95.5-96.7 \%$ similar to that of $P$. denitrificans LMG 4218, whereas those of $P$. versutus (sequences D32243 and D32244) were 99.1\% similar. They also reported that $P$. denitrificans strain IAM 12479 showed only $16-56 \%$ DNA-DNA hybridization with these six species and whereas the two strains of $P$. versutus (IAM 12814 and 12815) showed $98 \%$ hybridization with each other, they had only $18-26 \%$ hybridization with four other species. Hybridization of DNA from $P$. versutus IAM 12814 was only $51 \%$ with that from $P$. denitrificans IFO 13301 and $49-56 \%$ with $P$. denitrificans strain IAM 12479 (Katayama et al., 1995), thereby confirming our conclusion that $P$. versutus, $P$. denitrificans and $T$. pantotropha represent distinct genospecies. 
Table 2. DNA-DNA hybridization (\%) between strains DSM 65, 413', 11073 and 11104 of $P$. denitrificans and with $P$. versutus DSM 582

\begin{tabular}{|lcccc|}
\hline Strain number & DSM 65 & DSM 413 $^{\text {T }}$ & DSM 11073 & DSM 11104 \\
\hline DSM 65 & 100 & 58 & 71 & 89 \\
DSM 413 & 58 & 100 & 64 & 61 \\
DSM 11073 & 71 & 64 & 100 & 100 \\
DSM 11104 & 89 & 61 & 100 & 100 \\
DSM 582 & 54 & 59 & - & - \\
\hline
\end{tabular}

Table 3. Assignment of Paracoccus and Thiosphaera strains to $P$. denitrificans (group A on Fig. 1) and P. pantotrophus comb. nov. (group B on Fig. 1) on the basis of 165 rRNA gene sequence similarities and DNA-DNA hybridization (this study), and cytochrome $c$ profiles (Goodhew et al., 1996)

\begin{tabular}{|lc|}
\hline Paracoccus denitrificans (group A) & Paracoccus pantotrophus (group B) \\
\hline P. denitrificans ATCC $17741^{\mathrm{T}}$ & T. pantotropha ATCC $35512^{\mathrm{T}}$ \\
P. denitrificans LMD $22.21^{\mathrm{T}}$ & T. pantotropha LMD $82.5^{\mathrm{T} *}$ \\
P. denitrificans DSM $413^{\mathrm{T}}$ & T. pantotropha LMD 92.63 \\
P. denitrificans ATCC 19367 & P. denitrificans DSM $65 \dagger$ \\
P. denitrificans ATCC 13543 & P. denitrificans LMG 4218 \\
P. denitrificans IFO 13301 & P. denitrificans IAM 12479 \\
P. denitrificans DSM 1404 & P. denitrificans JCM 6892 \\
P. denitrificans DSM 1405 & P. denitrificans DSM 11072 \\
P. denitrificans NCIMB 8944 & P. denitrificans DSM 11073 \\
P. denitrificans strain Pd $1222 \ddagger$ & P. denitrificans DSM 11104 \\
\hline
\end{tabular}

*T. pantotropha strain GB17 , as used by Ludwig et al. (1993).

$\dagger$ Formerly regarded as the type strain of $P$. denitrificans.

$¥$ A derivative of $P$. denitrificans DSM $413^{\mathrm{T}}$.

\section{Conclusions and a proposal of the new combination $P$. pantotrophus comb. nov. to embrace $T$. pantotropha and some strains currently described as $P$. denitrificans}

The earlier studies of Goodhew et al. (1996) and Winterstein \& Ludwig (1998), along with our 16S rRNA sequence and DNA-DNA hybridization data, clearly demonstrate that the physiologically similar strains currently described as $P$. denitrificans actually fall into two distinct groups that differ so significantly that they justify classification as distinct species. These are here redefined as $P$. denitrificans and $P$. pantotrophus comb. nov. The type strain of $P$. denitrificans is ATCC $17741^{\mathrm{T}}$ (= LMD 22.21 ${ }^{\mathrm{T}}$; Beijerinck \& Minkman, 1910; Ludwig et al., 1993). The type strain of $P$. pantotrophus is ATCC $35512^{\mathrm{T}}\left(=\mathrm{LMD} 82.5^{\mathrm{T}}\right)$, which is the original isolate of $T$. pantotropha (Kuenen \& Robertson, 1989; Robertson \& Kuenen, 1983). Culture collection strains indicated by our work to be identical to each of these type strains are listed in Table 3. In addition, the work of Goodhew et al. (1996) and our reassessment of other published work indicates that the following strains are also $P$. denitrificans:
ATCC 13543, NCIMB 8944, strain Pd 1222, DSM 1404, DSM 1405 and IFO 13301. Recently, Winterstein \& Ludwig (1998) have shown that the genome of $P$. denitrificans ATCC 13453, DSM $413^{\mathrm{T}}$ and strain Pd 1222 consists of three chromosomes, whose DNA molecules are approximately $2 \cdot 1,1 \cdot 1$ and $0.64 \mathrm{Mb}$ in size. In contrast, $P$. denitrificans DSM 65 and $T$. pantotropha LMD $82.5^{\mathrm{T}}$ contained four large DNA species that were $2.2,1.50,1.71-1.77$ and $0.5 \mathrm{Mb}$ in size. This observation is wholly consistent with our confirmation of the first three species as $P$. denitrificans and the assignment of the latter two to the new combination, $P$. pantotrophus.

While it has long been recognized that the strains of $P$. denitrificans comprised several biotypes within a supposedly heterogeneous species (Jordan et al., 1997; Van Verseveld \& Stouthamer, 1992), our work, and that of Goodhew et al. (1996), has revealed a more significant factor underlying this heterogeneity. This is that the validity of reference strains held by different international culture collections as derivatives of the type strain ATCC $17741^{\mathrm{T}}$ is uncertain. Our results show that at some stage in the history of some culture 
collection strains supposedly derived from $P$. denitrificans LMD $22.21^{\mathrm{T}}$ (the organism originally isolated by Beijerinck \& Minkman, 1910) and ATCC $17741^{\mathrm{T}}$ switching with other strains (i.e. P. pantotrophus) must have occurred. It is clear that where comparison with a type strain is of crucial significance, as in defining a genotype or the identity of a strain with that type strain (in this case, ATCC $17741^{\mathrm{T}}$ ), reference to the authentic type strain held by the collection is essential. In the longer term, it is highly desirable that cross-checking by culture collection curators of the authenticity of all type strains and the authenticity of their putative derivatives is undertaken.

\section{Emended description of Paracoccus denitrificans (Beijerinck and Minkman 1910) Davis 1969, 384 ${ }^{\mathrm{AL}}$}

The formal genus and type species descriptions remain those given by Van Verseveld \& Stouthamer (1992) and Katayama et al. (1995), together with the emendation of the genus by Ludwig et al. (1993); but the emendation of the species description by Ludwig et al. (1993) must now be deleted. In addition, some if not all strains contain megaplasmids of at least $450 \mathrm{~kb}$ in size, but it is uncertain if they contain smaller $(100 \mathrm{~kb})$ plasmids, as none is present in strain DSM $413^{\mathrm{T}}$ or the 'Stanier strain 381', which was deposited with the

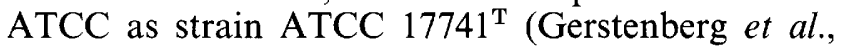
1982; Goodhew et al., 1996; Jordan et al., 1997). The type strain is ATCC $17741^{\mathrm{T}}\left(=\mathrm{LMD} 22.21^{\mathrm{T}}=\mathrm{DSM}\right.$ $413^{\mathrm{T}}$ ).

\section{Description of Paracoccus pantotrophus comb. nov. Robertson and Kuenen 1984a, 91 vP}

The formal description remains that given by Kuenen $\&$ Robertson (1989) for $T$. pantotropha, with the following additions (Arts et al., 1995; Goodhew et al., 1996; Jordan et al., 1997; Robertson et al., 1988): (1) some strains are capable of aerobic denitrification (simultaneous reduction of oxygen and nitrate) and heterotrophic nitrification (oxidation of ammonium to nitrite during heterotrophic growth); (2) some strains are capable of aerobic growth on formate, aerobic chemolithoautotrophic growth with carbon disulfide or carbonyl sulfide as energy substrates, methylotrophic growth on methanol or methylated sulfides, and heterotrophic growth on diethyl sulfide, thioethanol, thioacetic acid or substituted thiophenes; (3) some strains can grow anaerobically with denitrification on thiosulfate, carbon disulfide, methanol or formate as energy sources; (4) some strains contain plasmids of $85-110 \mathrm{~kb}$ in size and megaplasmids greater than $450 \mathrm{~kb}$ in size; (5) distinction from other species of Paracoccus can be confirmed by comparison of 16S rRNA gene sequence and DNA hybridization; (6) the amino acid sequence of its cytochrome $c-550$ differs by about $16 \%$ from that of $P$. denitrificans; and (7) the $\mathrm{G}+\mathrm{C}$ content of the DNA is $64-68 \mathrm{~mol} \%$ (type strain $\mathrm{G}+\mathrm{C}$ content is $66 \mathrm{~mol} \%$ ). The type strain is ATCC $35512^{\mathrm{T}}\left(=\operatorname{LMD} 82.5^{\mathrm{T}}\right)$.
We are very grateful to Celia Goodhew, Royal School of Veterinary Medicine, Edinburgh, and to Hans Hippe, DSMZ, Braunschweig, for providing a number of strains of $P$. denitrificans; to Simon Baker, University of Oxford, for providing a culture of Thiosphaera pantotropha LMD 92.63 and showing us unpublished data on FAMEs profiles of Paracoccus strains; and Bernd Ludwig for showing us data prior to publication.

Arts, P. A. M., Robertson, L. A. \& Kuenen, J. G. (1995). Nitrification and denitrification by Thiosphaera pantotropha in aerobic chemostat cultures. FEMS Microbiol Lett 18, 305-316.

Beijerinck, M. W. \& Minkman, D.C. J. (1910). Bildung und Verbrauch von Stickoxydul durch Bakterien. Zentbl Bakteriol Parasitenkd Infektionskr Hyg Abt II 25, 30-63.

Brosius, J., Palmer, M. L., Kennedy, J. P. \& Noller, H. F. (1978). Complete nucleotide sequence of a 16S ribosomal RNA gene from Escherichia coli. Proc Natl Acad Sci USA 75, 4801-4805.

Cashion, P., Holder-Franklin, M. A., McCully, J. \& Franklin, M. (1977). A rapid method for the base ratio determination of bacterial DNA. Anal Biochem 81, 461-466.

Chandra, T. S. \& Friedrich, C. G. (1986). $\mathrm{Tn}_{5}$ induced mutations in sulfur oxidizing ability (Sox) of Thiosphaera pantotropha. $J$ Bacteriol 166, 446-452.

Davis, H. D., Doudoroff, M. \& Stanier, R. Y. (1969). Proposal to reject the genus Hydrogenomonas: taxonomic implications. Int $J$ Syst Bacteriol 19, 375-390.

De Ley, J., Cattoir, H. \& Reynaerts, A. (1970). The quantitative measurement of DNA hybridization from renaturation rates. Eur J Biochem 12, 133-142.

Dobson, S. J. \& Franzmann, P. D. (1996). Unification of the genera Deleya (Baumann et al. 1983), Halomonas (Vreeland et al. 1980), and Halovibrio (Fendrich 1988) and the species Paracoccus halodenitrificans (Robinson \& Gibbons 1952) into a single genus, Halomonas, and placement of the genus Zymobacter in the family Halomonadaceae. Int $J$ Syst Bacteriol 46, $550-558$.

Escara, J. F. \& Hutton, J. R. (1980). Thermal stability and renaturation of DNA in dimethylsulphoxide solutions: acceleration of renaturation rate. Biopolymers 19, 1315-1327.

Felsenstein, J. (1993). PHYLIP (phyogenetic inference package) version 3.5.1. Department of Genetics, University of Washington, Seattle, WA, USA.

Gerstenberg, C., Friedrich, B. \& Schlegel, H. G. (1982). Physical evidence for plasmids in autotrophic, especially hydrogenoxidizing bacteria. Arch Microbiol 133, 90-96.

Goodhew, C. F., Pettigrew, G. W., Devreese, B., Van Beeumen, J., Van Spanning, R. J. M., Baker, S. C., Saunders, N., Ferguson, S. J. \& Thompson, I. P. (1996). The cytochromes c-550 of Paracoccus denitrificans and Thiosphaera pantotropha: a need for reevaluation of the history of Paracoccus cultures. FEMS Microbiol Lett 137, 95-101.

Harrison, A. P., Jr (1983). Genomic and physiological comparisons between heterotrophic thiobacilli and Acidiphilium cryptum, Thiobacillus versutus sp. nov., and Thiobacillus acidophilus nom. rev. Int J Syst Bacteriol 33, 211-217.

Hiraishi, A. (1992). Direct automated sequencing of 16S rDNA amplified by polymerase chain reaction from bacterial cultures without DNA purification. Lett Appl Microbiol 15, 210-213. 
Hiraishi, A., Shin, Y. K., Ueda, Y. \& Sugiyama, J. (1994). Automated sequencing of PCR-amplified 16S rDNA on 'Hydrolink' gels. J Microbiol Methods 19, 145-154.

Hiraishi, A., Kamagata, Y. \& Nakamura, K. (1995). Polymerase chain reaction amplification and restriction fragment length polymorphism analysis of $16 \mathrm{~S}$ rRNA genes from methanogens. $J$ Ferment Bioeng 79, 523-529.

Huß, V. A. R., Festl, H. \& Schleifer, K.-H. (1983). Studies on the spectrophotometric determination of DNA hybridization from renaturation rates. Syst Appl Microbiol 4, 184-192.

Jahnke, K.-D. (1992). BASIC computer program for evaluation of spectroscopic DNA renaturation data from GILFORD SYSTEM 2600 spectrophotometer on a PC/XT/AT type personal computer. J Microbiol Methods 15, 61-73.

Jordan, S. L., Kraczkiewicz-Dowjat, A. J., Kelly, D. P. \& Wood, A. P. (1995). Novel eubacteria able to grow on carbon disulfide. Arch Microbiol 163, 131-137.

Jordan, S. L., McDonald, I. R., Kraczkiewicz-Dowjat, A. J., Kelly, D. P., Rainey, F. A., Murrell, J. C. \& Wood, A. P. (1997). Autotrophic growth on carbon disulfide is a property of novel strains of Paracoccus denitrificans. Arch Microbiol 163, 225-236.

Jukes, T. H. \& Cantor, C. R. (1969). Evolution of protein molecules. In Mammalian Protein Metabolism, pp. 21-132. Edited by N. Munro. New York: Academic Press.

Katayama, Y., Hiraishi, A. \& Kuraishi, H. (1995). Paracoccus thiocyanatus sp. nov., a new species of thiocyanate-utilizing facultative chemolithotroph, and transfer of Thiobacillus versutus to the genus Paracoccus as Paracoccus versutus comb. nov. with emendation of the genus. Microbiology 141, 1469-1477.

Kuenen, J. G. \& Robertson, L. A. (1989). Genus Thiosphaera Robertson and Kuenen 1984a, 91 ${ }^{\mathrm{VP}}$. In Bergey's Manual of Systematic Bacteriology, vol. 3, pp. 1861-1862. Edited by J. T. Staley, M. P. Bryant \& J. G. Holt. Baltimore: Williams \& Wilkins.

Ludwig, W., Mittenhueber, G. \& Friedrich, C. G. (1993). Transfer of Thiosphaera pantotropha to Paracoccus denitrificans. Int $J$ Syst Bacteriol 43, 363-367.

Maidak, B. L., Larsen, N., McCaughey, M. J., Overbeek, R., Olsen, G. J., Fogel, K., Blandy, J. \& Woese, C. R. (1994). The Ribosomal Database Project. Nucleic Acids Res 22, 3485-3487.

Miller, J. M., Dobson, S. J., Franzmann, P. D. \& McMeekin, T. A.
(1994). Re-evaluating the classification of Paracoccus halodenitrificans with sequence comparisons of $16 \mathrm{~S}$ ribosomal DNA. Int J Syst Bacteriol 44, 360-361.

Ohara, M., Katayama, Y., Tsuzaki, M., Nakamoto, S. \& Kuraishi, H. (1990). Paracoccus kocurii sp. nov., a tetramethylammoniumassimilating bacterium. Int J Syst Bacteriol 40, 292-296.

Rainey, F. A., Ward-Rainey, N., Kroppenstadt, R. M. \& Stackebrandt, E. (1996). The genus Nocardiopsis represents a phylogenetically coherent taxon and a distinct actinomycete lineage: proposal of Nocardiopsiaceae fam. nov. Int J Syst Bacteriol 46, 1088-1092.

Robertson, L. A. \& Kuenen, J. G. (1983). Thiosphaera pantotropha gen. nov. sp. nov., a facultatively anaerobic, facultatively autotrophic sulphur bacterium. J Gen Microbiol 129, 28472855.

Robertson, L. A., van Niel, E. W. J., Torremans, R. A. M. \& Kuenen, J. G. (1988). Simultaneous nitrification and denitrification in aerobic chemostat cultures of Thiosphaera pantotropha. Appl Environ Microbiol 54, 2815-2818.

Siller, H., Rainey, F. A., Stackebrandt, E. \& Winter, J. (1996). Isolation and characterization of a new Gram-negative, acetone-degrading, nitrate-reducing bacterium from soil, Paracoccus solventivorans sp. nov. Int J Syst Bacteriol 46, 1125-1130.

Taylor, B. F. \& Hoare, D. S. (1969). New facultative Thiobacillus and a re-evaluation of the heterotrophic potential of Thiobacillus novellus. J Bacteriol 100, 487-497.

Urakami, T., Tamaoka, J., Suzuki, K.-I. \& Komagata, K. (1989). Paracoccus alcaliphilus sp. nov., an alkaliphilic and facultatively methylotrophic bacterium. Int J Syst Bacteriol 39, 116-121.

Urakami, T., Araki, H., Oyanagi, H., Suzuki, K.-I. \& Komagata, K. (1990). Paracoccus aminophilus sp. nov. and Paracoccus aminovorans sp. nov., which utilize $N, N$-dimethylformamide. Int $J$ Syst Bacteriol 40, 287-291.

Van Verseveld, H. W. \& Stouthamer, A. H. (1992). The genus Paracoccus. In The Prokaryotes. A Handbook on the Biology of Bacteria: Ecophysiology, Isolation and Identification, 2nd edn, pp. 2321-2334. Edited by A. Balows, H. G. Trüper, M. Dworkin, W. Harder \& K.-H. Schleifer. Berlin: Springer.

Winterstein, C. \& Ludwig, B. (1998). Genes coding for respiratory complexes map on all three chromosomes of the Paracoccus denitrificans genome. Arch Microbiol 169, 275-281. 